\title{
A study on relationship between market orientation's culture and exporting performance: A case study of manufacturing corporations listed on Tehran Stock Exchange
}

\author{
Omid Behboodi and Amir Ghafurian Shagerdi"
}

Department of Management and Accounting, International University of Imam Reza, Mashhad, Iran

\begin{tabular}{|c|c|}
\hline CHRON I C LE & A B S T R A T T \\
\hline $\begin{array}{l}\text { Article history: } \\
\text { Received August } 16,2013 \\
\text { Received in revised format } \\
12 \text { September } 2013 \\
\text { Accepted } 1 \text { November } 2013 \\
\text { Available online } \\
\text { November } 82013 \\
\text { Keywords: } \\
\text { Market Orientation }\end{array}$ & $\begin{array}{l}\text { Increasing trade, the globalization of products and services, as well as the internationalization } \\
\text { of specific firms have steadily accentuated the importance of export performance. This study } \\
\text { examines the relationship between market orientation culture with three components including } \\
\text { customer orientation, competitor orientation, interfunctional-coordination on increasing export } \\
\text { capabilities through firm age and size. Using the data gathered from } 111 \text { selected firms over the } \\
\text { period } 2006-2010 \text {, the study has applied correlation ratios as well as structural equation } \\
\text { modeling to examine various hypotheses. The survey has concluded that being market oriented } \\
\text { increases market capabilities through increasing firm size and age. }\end{array}$ \\
\hline
\end{tabular}

Customer Orien

Competitor Orientation

Tehran Stock Exchange

Exporting Performance

(c) 2013 Growing Science Ltd. All rights reserved.

\section{Introduction}

Over the past few years, substantial progress has been created on the market orientation area and the focus was on the definition, measurement, and effect of a market orientation. Attention has also concentrated on organizational drivers of market orientation and its enhancement (Jaworski \& Kohli, 1996; Kotler, 1977; Tuominen \& Möller, 1996). Market orientation is considered as the organizational culture, which most effectively and efficiently generates the required behaviors for the development of superior value for buyers and, thus, improves the performance for the business owners. Recently, there has been significant interest in the effect of marketing resources in contributing to the generation of competitive advantage and subsequently firm performance. Hooley et al. (2005) developed and empirically examined scales for measuring marketing resources and evaluated their effect on performance outcomes. They reported that marketing resources influence on financial performance indirectly through generating customer satisfaction and loyalty and creating superior market performance. Narver and Slater (1990) investigated the effect of a market orientation

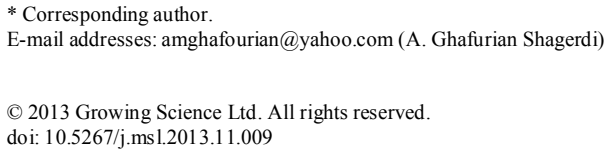


on business profitability and confirmed this effect through some empirical studies. Jaworski and Kohli (1993) performed an investigation on three issues, first, they tried to understand why some firms are more market-oriented than others do, determined the effect of a market orientation on employees and business performance and detected the relationship between a market orientation and business performance based on the environmental context. They reported that a market orientation was associated with top management emphasis on the orientation, risk aversion of top managers, interdepartmental conflict and connectedness, centralization, and reward system orientation.

According to Slater and Narver (1995), a market orientation, complemented by an entrepreneurial drive, provides the cultural basis for organizational learning. Nevertheless, as important as market orientation and entrepreneurship are, they ought to be complemented by a suitable climate to produce a "learning organization". Slater and Narver (1994) studied how competitive environment influences the strength of the market orientation-performance relationship and whether it influences the focus of the external emphasis within a market orientation within a given magnitude of market orientation. They reported very limited support for a moderator role for competitive environment on the market orientation-performance relationship. They believed the advantages of a market orientation are long term though environmental conditions (Zou \& Stan, 1998). Pelham (1997) investigated on relationship between market orientation and performance by looking into the moderating impacts of product and customer differentiation.

Julian (2010) investigated the relationship between market orientation and International Joint Venture (IJV) marketing performance by collecting some data from a self-administered mail survey of 831 Thai-Foreign IJVs in Thailand. They concluded that market orientation was a key antecedent of IJV marketing performance. The effect of market orientation on business performance has been extensively investigated over the past two decades and most people have agreed on its positive outcome especially for big size organizations. Mahmoud (2010), however, criticized that it was in this sector that firms required being more customer oriented to survive given evidence of their financial, technical and other constraints.

\section{The proposed study}

In this paper, we present the effects of three market orientation factors including customer oriented, competitor oriented and inter-functional coordination on export capabilities through influencing firm size and firm age. Fig. 1 demonstrates the structure of the proposed model.

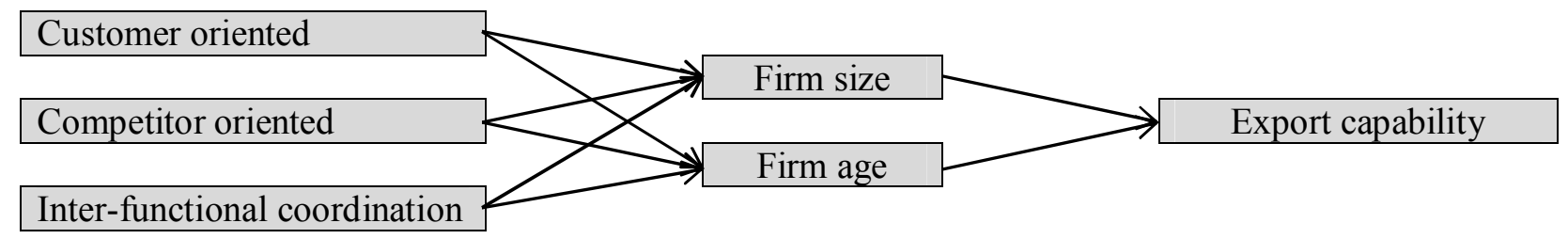

Fig. 1. The proposed study

The proposed study has performed on some selected firms, whose shares were traded on Tehran Stock Exchange based on the following criteria,

1. The study excluded holding firms, since it was difficult to gather the necessary information on these firms.

2. The shares of selected firms must have been traded from 2006 to 2010 and there was not long interruption in that period.

3. The firms must have exported their own products.

The proposed study determined the sample size as follows, 
$n=\frac{N \times z_{\alpha / 2}^{2} \times p \times q}{\varepsilon^{2} \times(N-1)+z_{\alpha / 2}^{2} \times p \times q}$,

where $N$ is the population size, $p=1-q$ represents the yes/no categories, $z_{\alpha / 2}$ is CDF of normal distribution and finally $\varepsilon$ is the error term. Since we have $p=0.5, z_{\alpha / 2}=1.96$ and $N=157$, the number of sample size is calculated as $n=111$. The survey designed a questionnaire consists of 28 questions in Likert scale and distributes it among some experts in selected firms. Cronbach alpha has been calculated as 0.891 , which is well above the minimum acceptable limit and validates the study. We first present details of our findings on verifying the Pearson correlation ratios, since the data was normally distributed, between three financial ratios, operating profit margin, return on assets (ROA), return on equities (ROE) on one side and three research variables including customer oriented, competitor oriented and inter-functional coordination. Table 1 demonstrates the results of our survey.

\section{Table 1}

The summary of Pearson correlation ratios

\begin{tabular}{lccc}
\hline & Customer oriented & Competitor oriented & Inter-functional coordination \\
\hline Operating profit margin & 0.072 & 0.573 & 0.681 \\
ROA & 0.405 & -0.222 & 0.303 \\
ROE & -0.184 & -0.261 & 0.364 \\
\hline
\end{tabular}

As we can observe from the results of Table 1, there are some positive and strong correlation between Operating profit margin and being competitor oriented $(\mathrm{r}=0.573)$, a strong relationship between Operating profit margin and Inter-functional coordination $(\mathrm{r}=0.681)$. In addition there was a mild and positive correlation ratio between ROA and Customer oriented ( $\mathrm{r}=0.405)$, between ROA and Interfunctional coordination $(\mathrm{r}=0.303)$ and between ROE an Inter-functional coordination $(\mathrm{r}=0.364)$. The study has detected a negative relationship between being competitor oriented and ROA $(r=-0.222)$ and ROE (-0.261) and there was a negative relationship between ROE and being customer oriented. In terms of export factors since the components were not normally distributed, the study has applied Spearman correlation ratios. Table 2 summarizes the results of our survey.

\section{Table 2}

The summary of Spearman correlation ratios on the success of export

\begin{tabular}{lccc}
\hline & Customer oriented & Competitor oriented & Inter-functional coordination \\
\hline Management perception & 0.227 & 0.076 & 0.306 \\
Management satisfaction & 0.238 & 0.162 & 0.339 \\
Management target achievement & 0.341 & 0.333 & 0.504 \\
\hline
\end{tabular}

The results of Table 2 show that there are some positive correlations between management target achievement and Inter-functional coordination $(\mathrm{r}=0.504)$, between management target achievement and being customer oriented, between management satisfaction and inter-functional coordination $(\mathrm{r}=0.339)$ and between management perception and inter-functional coordination $(\mathrm{r}=0.306)$.

\section{The results}

In this section, we present details of the implementation of structural equation modeling (SEM) on testing the relationship between various components of the survey.

Table 3

The summary of standard coefficients of the implementation of SEM

\begin{tabular}{lccc}
\hline & Direct standard coefficient & Indirect non-standard coefficient & Indirect standard coefficient \\
\hline Firm size & 0.223 & - & - \\
Firm age & 0.479 & - & - \\
$\begin{array}{l}\text { Inter-functional } \\
\text { coordination }\end{array}$ & 0 & 0.286 & 0.227 \\
Competitor oriented & 0 & 0 & 0.197 \\
Competitor oriented & 0 & 0.265 & 0 \\
\hline
\end{tabular}


To understand the relationship between various components of the model, we demonstrate them in Fig. 2 as follows,

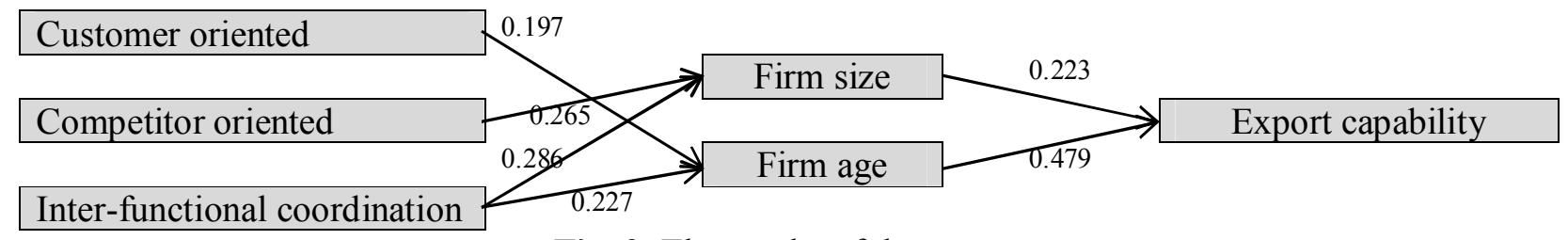

Fig. 2. The results of the survey

The results of Fig. 2 show that being customer oriented influences positively on firm age $(\beta=0.197)$, being competitor oriented has some positive impact on firm size $(\beta=0.265)$, Inter-functional coordination influence both firm size $(\beta=0.286)$ and firm age $(\beta=0.227)$. Finally, firm size influences export capability $(\beta=0.223)$ and firm age influences export capability $(\beta=0.479)$. Therefore, being market oriented will positively influence on export capabilities and it will improve market share.

\section{Conclusion}

In this paper, we have presented an empirical investigation to study the impact of being customer oriented on developing export capabilities on some selected firms from Tehran Stock Exchange. The proposed study selected some firms over the period 2006-2010 and using correlation techniques as well as structural equation modeling has determined that being market oriented would increase export capabilities through increasing firm size and age.

\section{References}

Dornberger, U., Noor Un Nabi, M., \& Linh, L. D. (2010). The impact of market orientation on the performance of the Vietnamese software firms.

Hooley, G. J., Greenley, G. E., Cadogan, J. W., \& Fahy, J. (2005). The performance impact of marketing resources. Journal of Business Research, 58(1), 18-27.

Jaworski, B. J., \& Kohli, A. K. (1993). Market orientation: antecedents and consequences. The Journal of marketing, 53-70.

Jaworski, B. J., \& Kohli, A. K. (1996). Market orientation: review, refinement, and roadmap. Journal of Market-Focused Management, 1, 119-135.

Julian, C. C. (2010). The market orientation-marketing performance relationship: the empirical link in international joint ventures. International Journal of Trade and Global Markets, 3(4), 414-431.

Kotler, P. (1977). From sales obsession to marketing effectiveness. Graduate School of Business Administration, Harvard University.

Mahmoud, M. A. (2010). Market orientation and business performance among SMEs in Ghana. International Business Research, 4(1), p241.

Narver, J. C., \& Slater, S. F. (1990). The effect of a market orientation on business profitability. The Journal of Marketing, 20-35.

Pelham, A. M. (1997). Market orientation and performance: the moderating effects of product and customer differentiation. Journal of Business \& Industrial Marketing, 12(5), 276-296.

Slater, S. F., \& Narver, J. C. (1995). Market orientation and the learning organization. The Journal of Marketing, 63-74.

Slater, S. F., \& Narver, J. C. (1994). Does competitive environment moderate the market orientationperformance relationship?. The Journal of Marketing, 58(1), 46-55.

Tuominen, M., \& Möller, K. (1996). Market orientation: a state-of-the-art review. Proceedings of the 25Th European Marketing Academy Confrence, Budapest, Hungary, 1161-1181.

Zou, S., \& Stan, S. (1998). The Determinants of Export performance. International Marketing Review, 15, 333-356. 